\title{
Secondary Drug Toxiderma to Allopurinol: About 23 Cases
}

\author{
Bouighjdane F*, Mahhou M, Benmoussa S, Hocar O, Amal S
}

Department of Dermatology and Venereology, UHC Mohammed VI, FMPM, UCA, Marrakech

DOI: $10.36347 /$ sasjm.2020.v06i01.005

| Received: 15.01.2020 | Accepted: 22.01.2020 | Published: 29.01.2020

*Corresponding author: Bou Ighjdane Fatiha

\section{Abstract}

Allopurinol is a commonly prescribed uric brake drug. However, it is one of the main drugs providing serious toxiderma such as Lyell, Stevens-Johnson syndromes and drug hypersensitivity syndrome or drug rash with eosinophilia and systemic symptoms (DRESS). We carried out a retrospective study, carried out at the dermatology department of the CHU Mohammed VI of Marrakech over a period of 16 years from January 2003 to September 2019. We included all cases of allopurinol toxiderma diagnosed during the study period. The parameters studied are age, sex, associated defects, time to onset of toxiderma, clinical form, length of hospital stay and evolution. We have collected 100 cases of toxiderma, including 23 due to allopurinol $(23 \%)$. Our patients were aged 18 to 76 with an average of 59.1 years. The sex ratio was 3.25 with a clear female predominance. $47 \%$ of our patients were diabetic, $35 \%$ were hypertensive and $29.4 \%$ were followed for chronic renal failure. Only 2 of our patients were on Allopurinol alone. Clinically, the main form found was Stevens Johnson syndrome in $47 \%$ followed by generalized acute exanthematic pustulosis and DRESS syndrome with $17.6 \%$ each and then rash maculo -papular with $11.7 \%$ and erythroderma in one case. These toxiderma required hospitalization ranging from 2 to 24 days with an average of 13.4 days. The evolution was favorable in almost all cases with only one death.

Keywords: Allopurinol, serious toxiderma, dermatology, toxiderma.

Copyright @ 2020: This is an open-access article distributed under the terms of the Creative Commons Attribution license which permits unrestricted use, distribution, and reproduction in any medium for non-commercial use (NonCommercial, or CC-BY-NC) provided the original author and source are credited.

\section{INTRODUCTION}

Allopurinol is a commonly prescribed uric brake drug. However, it is one of the main drugs providing serious toxiderma such as Lyell, StevensJohnson syndromes and drug hypersensitivity syndrome or drug rash with eosinophilia and systemic symptoms (DRESS).

\section{METHODS}

This is a retrospective study, carried out at the dermatology department of the CHU Mohammed VI of Marrakech over a period of 16 years from January 2003 to September 2019. We included all cases of allopurinol toxiderma diagnosed during the period study. The parameters studied are age, sex, associated defects, time to onset of toxiderma, clinical form, length of hospital stay and evolution

\section{RESULTS}

We have collected 100 cases of toxiderma, including 23 due to allopurinol (23\%). Our patients were aged 18 to 76 with an average of 59.1 years. The sex ratio was 3.25 with a clear female predominance. $47 \%$ of our patients were diabetic, $35 \%$ were hypertensive and $29.4 \%$ were followed for chronic renal failure. Only 2 of our patients were on Allopurinol alone. The main co-medication was angiotensin converting enzyme inhibitors in $29.4 \%$ followed by metformin in $23.5 \%$ of cases and insulin and angiotensin receptor antagonists in $11,7 \%$ of cases each. The association with indomethacin, amoxicillin, diuretics and beta blockers was found in one case each. The time to onset for toxiderma was 4 to 35 days after starting to take allopurinol with an average of 27.2 days. Clinically, the main form found was Stevens Johnson syndrome in $47 \%$ followed by generalized acute exanthematic pustulosis and DRESS syndrome with $17.6 \%$ each, then maculopapular rash with $11.7 \%$ and erythroderma in one case. These toxiderma required hospitalization ranging from 2 to 24 days with an average of 13.4 days. The treatment consisted in stopping allopurinol and daily bathing in all our patients, antihistamines were prescribed in $23.5 \%$ of cases. The evolution was favorable in almost all cases with a single death in a table of functional renal failure and hydroelectrolytic disorders with hyperkalaemia and hyponatraemia. 


\section{DISCUSSION}

Allopurinol is a powerful blood uricemic agent, it inhibits xanthine oxidase, which is an enzyme catalyzing the biosynthesis of uric acid. Several publications incriminate him in potentially serious toxiderma. The European multinational study to monitor cases of severe cutaneous adverse reactions (euroSCAR) was carried out in 6 countries (Austria, France, Germany, Israel, Italy, and the Netherlands) between April 1997 and December 2001. She reported that allopurinol is the most common drug for Lyell syndrome, and Stevens-Johnson syndrome (SSJ) in Europe and Israel with a rate of $17.4 \%$ among 379 patients [1]. The same results were described by Lin et al. in a study carried out in Taiwan on 35 patients with a rate of $17 \%$ [2]. Our results agree with the literature with a rate of $23 \%$.

A slight female predominance was found in the EuroSCAR study with $59 \%$ of women with an average age of 64 years [1]. Chau Yee et al. reported a study of 146 cases of allopurinol toxiderma. Males accounted for $55 \%$ of the cases and the age varied between 18 and 88 years with an average of 65 years [3]. Our patients were 18 to 76 years old with an average of 59.1 years and $76.4 \%$ were women.

The time between the start of treatment and the onset of drug addiction is variable. According to EuroSCAR, the first 8 weeks of treatment need maximum precaution since $95 \%$ of SSJ and Lyell syndrome occur during this period [1]. Our results agree with the literature. $100 \%$ of toxiderma occurred within less than 6 weeks with an average of 27.2 days.

Furthermore, it seems that the risk of toxiderma is dose dependent. The administration of allopurinol at a dose $\geq 200 \mathrm{mg} /$ day was noted in $95 \%$ of subjects with SSJ or Lyell syndrome in the EuroSCAR study [1]. Other studies by Yang et al. and Kuo et al. in Taiwan have reported severe toxiderma even at low doses of allopurinol $[4,5]$.

The cutaneous manifestations of allopurinol toxiderma are variable. They can be mild a maculopapular rash type or be life-threatening in the event of DRESS, SSJ or even Lyell syndrome. Of the 146 cases reported by Chau Yee et al. $40 \%$ had a DRESS, 27\% had a papular rash, 21\% had SSJ and 9\% had Lyell syndrome [3]. In our study, the main form found was Stevens Johnson syndrome in $47 \%$ followed by generalized acute exanthematic pustulosis and DRESS syndrome with $17.6 \%$ each, then maculopapular rash in $11.7 \%$ and erythroderma in a case.

The HLA-B * 58: 01 antigen appears to be incriminated in allopurinol toxiderma and mainly the severe forms. Chau Yee et al. demonstrated that $83 \%$ of the cases having presented a toxiderma among their series were carrying the HLA-B * 58: 01 antigen. This rate was higher for serious toxidermies with a rate of 93\% for Lyell's syndromes, $91 \%$ for DRESS, $88 \%$ for SSJ and $65 \%$ for maculopapular rashes [3]. In addition, renal failure defined by a glomerular filtration rate DFG $<30 \mathrm{ml} / \mathrm{min} / 1.73 \mathrm{~m} 2$ was found in $95 \%$ of cases. In these patients, the accumulation of oxypurinol, the metabolite of allopurinol with renal elimination, could cause hypersensitivity reactions according to Yun et al. The coexistence of HLA-B * 58: 01 and kidney failure is accompanied by a significant increase in the risk of serious toxiderma. $29.4 \%$ of patients had chronic renal failure [6].

The association of renal failure appears to be correlated with the severity of toxiderma and with mortality. According to Chau Yee et al. $83 \%$ of the deceased patients had a renal function $<30 \mathrm{ml} / \mathrm{min} /$ $1.73 \mathrm{~m} 2$ and these authors suggest to ban the use of allopurinol in the event of coexistence of HLA-B $* 58$ : 01 and insufficiency kidney with a GFR $<30 \mathrm{ml} / \mathrm{min} /$ $1.73 \mathrm{~m} 2$ [3].

Several publications suspect the role of the interaction of certain drugs including aminopenicillins, angiotensin converting enzyme inhibitors, acetylsalicylic acid and diclofenac in the genesis of Allopurinol toxiderma. But according to the EuroSCAR study, this co-medication is not associated with an increased risk [1]. Co-medication was found in $88.2 \%$ of our patients represented mainly by Angiotensinconverting Enzyme Inhibitors in $29.4 \%$ followed by metformin in $23.5 \%$ of the cases and insulin in $11.7 \%$.urique et calcique, des déficits en adénine phosphoribosyl transférase (APRT) et des syndromes de Lesch-

The death rate secondary to toxidermia varies in the literature. It is $32 \%$ in the serious toxiderma for the study of EuroSCAR [1]. For Chau Yee et al. this rate is $8 \%$ of all toxiderma [3]. In our study, we report a single death in a table of functional renal failure with hydro-electrolyte disorders. Using allopurinol as directed could significantly reduce the morbidity and mortality from severe toxiderma. Halevy et al. estimate that 100 cases of SSJ and Lyell syndromes and 30 deaths could thus be avoided each year in Europe [1].

\section{CONCLUSION}

The aim of our work is to draw the clinician's attention to the possibility of serious drug reactions with allopurinol and to remind the need to comply with the indications having Marketing Authorization.

\section{REREFENCES}

1. Halevy S, Ghislain PD, Mockenhaupt M, Fagot JP, Bavinck JN, Sidoroff A, Naldi L, Dunant A, Viboud C, Roujeau JC, EuroSCAR Study Group. Allopurinol is the most common cause of StevensJohnson syndrome and toxic epidermal necrolysis 
in Europe and Israel. Journal of the American Academy of Dermatology. 2008 Jan 1;58(1):25-32.

2. Lin MS, Dai YS, Pwu RF, Chen YH, Chang NC. Risk estimates for drugs suspected of being associated with Stevens-Johnson syndrome and toxic epidermal necrolysis: a case-control study. Internal medicine journal. 2005 Mar;35(3):188-90.

3. Ng CY, Yeh YT, Wang CW, Hung SI, Yang CH, Chang YC, Chang WC, Lin YJ, Chang CJ, Su SC, Fan WL, Chen DY, Wu Y-JJ, Tian YC, Hui RCY, Chung WH, Taiwan Severe Cutaneous Adverse Reaction Consortium, Impact of the HLAB*58:01allele andrenal impairment on allopurinolinduced cutaneous adverse reactions, The Journal of Investigative Dermatology. 2016

4. Kuo HW, Tsai SS, Tiao MM, Yang CY. Epidemiological features of CKD in Taiwan. Am J Kidney Dis. 2007;49:46-55.

5. Yang CY, Chen CH, Deng ST, Huang CS, Lin YJ, Chen YJ, Wu CY, Hung SI, Chung WH. Allopurinol use and risk of fatal hypersensitivity reactions: a nationwide population-based study in Taiwan. JAMA internal medicine. 2015 Sep 1;175(9):1550-7.

6. Yun J, Mattsson J, Schnyder K, Fontana S, Largiadèr CR, Pichler WJ, Yerly D. Allopurinol hypersensitivity is primarily mediated by dosedependent oxypurinol-specific $\mathrm{T}$ cell response. Clinical \& Experimental Allergy. 2013 Nov;43(11):1246-55.

7. Devlin JW, Bellamy N, Bayliff CD. Observations and effects of educational consults on allopurinol prescribing. Can J HospPharm. 1992;45:21-7

8. Singer JZ, Wallace SL. The allopurinol hypersensitivity syndrome: unnecessary morbidity and mortality. Arthritis Rheum. 1986;29:82-7.

9. Bellamy N, Brooks PM, Emmerson BT, Gilbert JR, Campbell J, McCredie M. A survey of current prescribing practices of anti-inflammatory and urate-lowering drugs in gouty arthritis inNew South Wales and Queensland. Med J Aust. 1989;151:531-2,535-7.

10. Zell SC, Carmichael JM. Evaluation of allopurinol use in patients with gout. American Journal of Health-System Pharmacy. 1989 Sep 1;46(9):18136.

11. Stuart RA, Gow PJ, Bellamy N, Campbell J, Grigor R. A survey ofcurrent prescribing practices of antiinflammatory and urate-lowering drugs in gouty arthritis. N Z Med J. 1991;104:115-7.

12. Khoo BP, Leow YH. A review of inpatients with adverse drugreactions to allopurinol. Singapore Med J . 2000; 41:156-60.

13. Agence nationale de sécurité du médicament (ANSM). Commission nationale de pharmacovigilance. Compte rendu dela réunion du mardi 27 mars. 2012; 2012.

14. Atzori L, Pinna AL, Mantovani L, Ferreli C, Pau M, Mulargia M, Aste N. Cutaneous adverse drug reactions to allopurinol: 10 year observational survey of the dermatology department-Cagliari University (Italy). Journal of the European Academy of Dermatology and Venereology. 2012 Nov;26(11):1424-30.

15. Demange C, Ghionoiu I, Benhammadi D. Allopurinol: enquête de pratique dans un centre hospitalier. Le Pharmacien Hospitalier et Clinicien. 2016 Sep 1;51(3):241-4. 